\title{
Article \\ Antibacterial Efficacy of Some Medicinal Plants on Multidrug Resistance Bacteria and Their Toxicity on Eukaryotic Cells
}

\author{
Sereen M. B. Bataineh ${ }^{1, *}$, Yaser H. Tarazi ${ }^{2}$ and Wafá A. Ahmad ${ }^{3}$ \\ 1 Department of Biotechnology and Genetic Engineering, Faculty of Science and Art, \\ Jordan University of Science and Technology, Irbid 22110, Jordan \\ 2 Department of Basic Medical Veterinary Sciences, Faculty of Veterinary Medicine, \\ Jordan University of Science and Technology, Irbid 22110, Jordan; tarazi@just.edu.jo \\ 3 Department of Applied Biological Sciences, Faculty of Science and Art, \\ Jordan University of Science and Technology, Irbid 22110, Jordan; wafaaadnanahmad@yahoo.com \\ * Correspondence: smbataineh3@just.edu.jo
}

Citation: Bataineh, S.M.B.; Tarazi, Y.H.; Ahmad, W.A. Antibacterial Efficacy of Some Medicinal Plants on Multidrug Resistance Bacteria and Their Toxicity on Eukaryotic Cells. Appl. Sci. 2021, 11, 8479. https:// doi.org/10.3390/app11188479

Academic Editor: Patrizia Messi

Received: 1 August 2021

Accepted: 2 September 2021

Published: 13 September 2021

Publisher's Note: MDPI stays neutral with regard to jurisdictional claims in published maps and institutional affiliations.

Copyright: (c) 2021 by the authors. Licensee MDPI, Basel, Switzerland. This article is an open access article distributed under the terms and conditions of the Creative Commons Attribution (CC BY) license (https:/ / creativecommons.org/licenses/by/ $4.0 /)$.

\begin{abstract}
The aim of this study was to evaluate the in vitro antimicrobial activity of medicinal methanolic plant extracts against multidrug-resistant bacteria to determine the cytotoxicity of these extracts on eukaryotic cells, and to confirm their efficacy against Methicillin-Resistant Staphylococcus aureus (MRSA) in experimental animals. The effects of the methanol extract of sixty folk plants were investigated on; MRSA, Extended Spectrum Beta-Lactamase E. coli and MDR Pseudomonas aeruginosa by disc diffusion and MIC assay. Cytotoxicity was determined using MTT and hemolysis of human erythrocytes. Three plant extracts with the highest antimicrobial activities were tested using a challenge experiment on mice. Systemic infection was performed by intraperitoneal inoculation of $\left(5 \times 10^{6} \mathrm{CFU} / \mathrm{mL}\right)$ of MRSA isolate. Then mice received $300 \mathrm{mg} / \mathrm{kg}$ body weight of the plant extracts daily for seven days. The efficacy of plant extracts was evaluated by general health, mortality rate, gross lesion, and histopathology study of inoculated mice. Only ten plants showed activities against different MDR bacteria with inhibitory zones ranging from (8 to $22 \mathrm{~mm}$ ) in diameter. Of the ten medicinal plant extracts, Camellia sinensis and Aloysia citrodora showed the highest activities against MRSA and MSSA isolates, with MIC value ranging from 0.5 to $1.5 \mathrm{mg} / \mathrm{ml}$, followed by Hibiscus sabdariffa, Thymus vulgaris, and Glycyrrhiza glabra. Furthermore, the extract of the effective plants showed low toxicity against Vero and fibroblasts cell lines, along with inhibitory activities to erythrocytes membrane disruption. The in vivo study demonstrated that Camellia sinensis showed significant activity against MRSA infections in mice. The results validate that these plants are effective and safe antibacterial agents against multidrug-resistance bacteria, and have the potential to be utilized as an alternative to antibiotics for the treatment of bacterial infections.
\end{abstract}

Keywords: medicinal plants; antibacterial efficacy; MRSA; ESBLEC; MDR P. aeruginosa

\section{Introduction}

The alarming increase in infectious diseases has become a serious global health problem, with a significant increase in morbidity and mortality due to extensive use and misuse of antibiotics [1,2]. Recently, more bacteria have become resistant to available antibiotics [3,4]. The Infectious Diseases Society of America recognizes antimicrobial resistance as "one of the most important threats to human health worldwide" [5]. The most famous resistance patterns are; Methicillin-Resistant Staphylococcus aureus (MRSA), Extended Spectrum Beta-Lactamase Escherichia coli (ESBLEC) and Pseudomonas aeruginosa. For these reasons, it is necessary to search for the possibility of finding an alternative novel and effective antibacterial agent against multidrug-resistant bacteria.

The spread of antibiotic resistance is continuously occurring, and it is a nonstop process, but it can be slowed [6]. The best solution is to invest in the development of new antimicrobial compounds from plant sources [7]. Chemical compounds isolated from 
plants that are characterized as antimicrobial agents are significant and differ in structures and activity against bacterial pathogens [8,9]. Plant-derived products are an attractive source of antimicrobial agents considering they are natural and affordable, nontoxic to host and active at low concentrations [10-12]. Numerous recent studies have reported plant components that have antimicrobial properties and are effective against a wide spectrum of Gram positive and Gram negative bacteria, fungi, and viruses [13]. Methanol plant extracts were used to evaluate their antimicrobial effects. A comparative study performed by [14], showed that methanol extraction yield high content of phenolic, flavonoid, alkaloid and terpenoids. They also revealed high antioxidant capacity and promising anti-inflammatory activity when compared with other extracts such as ethanol, chloroform, dichloromethane, acetone, gallic acid and ascorbic acid. The Arab world is blessed with diverse climate conditions which enable the growth of a wide variety of plants [15]. Many folk herbal plants used in traditional remedies are still unexplored, and many of them need studies to ensure that they can be used as drugs for different infectious diseases caused by multidrugresistant bacteria. According to the world health organization, medicinal plants would be the best source for getting a diversity of drugs [16].

Traditional plants may contain compounds that have adverse effects on humans [17]. Contrarily, plants associated microorganisms referred to as phytomicrobiome have the potential to secrete metabolites important industrially, in medicine and for environmental preservation [18]. Toxicity profiling is crucial to evaluate the use of traditional plants or their bioactive compound in human consumption [19]. MTT assay enzyme-based method is the best-known method, which refers to the normal function of mitochondria in a living cell through cellular reduction reaction involves the pyridine nucleotide cofactors NADH/NADPH [20]. The erythrocyte hemolysis assay has been widely used to evaluate membrane stabilizing activities as a general indication of membrane toxicity [21].

It is very important to associate in vitro antimicrobial and cytotoxicity assay with in vivo toxicity using animal models. The systemic toxicity test was evaluated toxicity in tested animals following a given oral, dermal, or inhalation exposure, according to routes of human exposure. Challenge test focused on in vivo validation of the antimicrobial potential of plants is in need. Therefore, the aims of this study were to evaluate the in vitro antimicrobial characteristics of sixty folks medicinal methanolic plant extracts used in Jordan against multidrug resistance bacteria; MRSA, MSSA, ESBL E. coli, and MDR $P$. aeruginosa, to determine the cytotoxicity of these plant extracts on eukaryotic cells, and to confirm the efficacy of these plants against MRSA in mice.

\section{Materials and Methods}

\subsection{Bacterial Strains}

Ten isolates of ESBLs E. coli, 10 MRSA, 10 MSSA, and 5 MDR P. aeruginosa were used in this study. All of these bacterial strains were isolated from clinical and animal specimens and characterized by multi-drug resistant profiles. The isolates were obtained from the stock culture of Microbiology Research laboratory, Faculty of Veterinary Medicine, Jordan University of Science and Technology. Reference strains of E. coli (NTCC O157), S. aureus (ATCC 25923), MRSA (ATCC 93300), and P. aeruginosa (ATCC 9027) were also used.

\subsection{Plant Collection and Preparation}

Sixty plants were collected from local market at Amman and from the Faculty of Pharmacy (JUST). One hundred grams of each air-dried plant sample were extracted using $500 \mathrm{~mL}$ of absolute methanol (Waltham, MA, USA) with continuous shaking using a rotary shaker machine (Micra Technologies, Haryana, India) for $72 \mathrm{~h}$ at room temperature. The whole mixture was filtered and evaporated at $40{ }^{\circ} \mathrm{C}$ under reduced pressure using rotary evaporator (Buchi R-215, Schwabach, Switzerland); the total volume was reduced to $10 \mathrm{~mL}$ and dried using water bath (Memmert, Schwabach, Germany) and vacuum desiccator (Sartorious AG, Gottingen, Germany). Out of the sixty screened plants ten were selected after a rapid examination to determine their anti-bacterial effect (Table 1). 
Table 1. Scientific and common names of the medicinal plants that have potential antibacterial activity used in this study.

\begin{tabular}{cccccc}
\hline Plant Number & Scientific Name & Family & Common Name & Arabic Name & Plant Form \\
\hline 1 & Camellia sinensis & Theaceae & Green tea & Shay Akhdur & Herb \\
2 & Hibiscus sabdariffa & Malvaceae & Roselle & Karkadeh & Flower \\
3 & Aloysia citrodora & Verbenaceae & lemon verbena & Lemon Aloysia & Herb \\
4 & Glycyrrhiza glabra & Fabaceae & Liquorice & Erqsus & Root \\
5 & Thymus vulgaris & Lamiaceae & Thyme & Za'atar & Herb \\
6 & Urtica pilulifera & Urticaceae & Nettles & Qarass & Shrub \\
7 & Phlomis brachyodon & Lamiaceae & Phlomis & Jerusalem Sage & Shrub \\
8 & Plantago lanceolata & Plantaginaceae & Plantain & Lamb's Tongue & Shrub \\
9 & Anchusa azurea & Boraginaceae & Bugloss & Blue Bull Tongue & Flower \\
10 & Pallenis spinosa & Asteraceae & Spiny golden star & Al najmeiah & \\
\hline
\end{tabular}

\subsection{In Vitro Antibacterial Activities Assay}

\subsubsection{Disc Diffusion Assay}

One hundred $\mathrm{mg}$ of the dried plant extracts were dissolved in $10 \%$ dimethylsulfoxide (DMSO) (Sigma, Hamburg, Germany) to a final concentration of $100 \mathrm{mg} / \mathrm{mL}$ and sterilized by filtration through $0.22 \mu \mathrm{m}$ cellulose membrane filter (Indiamart, Vadodara, India). The modified disc diffusion assay was performed using $6 \mathrm{~mm}$ filter paper disc (Oxoid, UK) that was impregnated with $50 \mu \mathrm{L}$ plant extract $(10 \mathrm{mg} /$ disc) at a concentration of $200 \mathrm{mg} / \mathrm{mL}$ and kept at room temperature for one hour [13]. The bacterial broth culture was adjusted to (0.5) McFarland turbidity, and then streaked evenly onto Müller Hinton agar. The plant extract discs and antibiotic discs were applied on the surface of Mueller Hinton Agar MHA (Oxoid, UK) plates and incubated under aerobic conditions at $37^{\circ} \mathrm{C}$ for $24 \mathrm{~h}$. The tests were carried out in triplicate. Zone of inhibition $\geq 11 \mathrm{~mm}$ indicates susceptibility of the tested bacteria and consider as high antibacterial activity [22]. The inhibition of bacterial growth was evaluated by measuring the diameter $(\mathrm{mm})$ of the clear zone around each disc [23]. Vancomycin (10 $\mu \mathrm{g} /$ disc) (Oxoid, UK) and gentamycin (10 $\mu \mathrm{g} /$ disc) (Oxoid, UK) were used as a positive control, while DMSO was used as a negative control [13].

\subsubsection{Minimum Inhibitory Concentration Assay (MIC) and Minimum Bactericidal Concentration Assay (MBC)}

The plants that showed antibacterial activity by disc diffusion assay were further tested by microdilution assay. The initial plant extracts concentration $(100 \mathrm{mg} / \mathrm{mL})$ was diluted by two-fold dilution manner in MHB in 96 well plates (50, 25, 12.5, 6.25, 3.125, 1.56, $0.78,0.39$, and $0.19 \mathrm{mg} / \mathrm{mL}$ ). One hundred $\mu \mathrm{L}$ bacterial inoculum size of $1 \times 10^{6} \mathrm{CFU} / \mathrm{mL}$ was added to each well except the negative control, so the final inoculum size become $5 \times 10^{5} \mathrm{CFU} / \mathrm{mL}$. The positive control was vancomycin for Gram positive bacteria and gentamycin for Gram negative bacteria. Wells containing the bacterial inoculum were used as positive control and wells containing plant extract as a negative control. Each plant extract was run in triplicate. The MIC considered as the lowest concentration of plant extract dilution that inhibited any visible growth of the tested bacteria. Bacterial growth in each sample was confirmed by adding $40 \mu \mathrm{L}$ indicator solution $(0.2 \mathrm{mg} / \mathrm{mL}) \mathrm{p}$ iodonitrotetrazolium chloride (INT) (ZellBio, Lonsee, Deutschland, Germany) to every well and incubated at $37^{\circ} \mathrm{C}$ for $30 \mathrm{~min}$. The microbial activity was indicated by the formation of a pink-red color while inhibition of the growth was observed by the continuation of purple color, and the color changes were assessed visually. The lowest concentration that prevented the purple color change was considered as the MIC $[19,24]$. The MBC was determined by adding $50 \mu \mathrm{L}$ aliquots of the extract preparations that did not show any growth after incubation during MIC assays, to $150 \mu \mathrm{L}$ broth in the 96-well plate (Sigma, Hamburg, Germany). These preparations were incubated at $37^{\circ} \mathrm{C}$ for $48 \mathrm{~h}$. The MBC was regarded as the lowest concentration of extract, which did not produce a color change after addition of INT as mentioned above. Bacterial growth in each sample was confirmed by adding $40 \mu \mathrm{L}$ indicator solution $(0.2 \mathrm{mg} / \mathrm{mL})$ p-iodonitrotetrazolium chloride (INT) 
to every well and incubated at $37^{\circ} \mathrm{C}$ for $30 \mathrm{~min}$. The microbial activity was indicated by the formation of a pink-red color while inhibition of the growth was observed by the continuation of purple color, and the color changes were assessed visually. The lowest concentration that prevented the purple color change was considered as the MIC and the MBC was considered as the lowest concentration of plant extract that did not produce a color change after addition of INT $[19,24]$.

\subsection{Cytotoxicity Assay}

\subsubsection{The Erythrocyte Hemolysis}

Erythrocytes were obtained from human blood by removing the plasma and buffy coat by centrifugation at $5000 \mathrm{rpm}$ for five minutes, then was suspended in phosphatebuffered saline (10 Mm phosphate, $150 \mathrm{Mm}$ sodium chloride (Sigma, Hamburg, Germany)) making a final concentration of $2 \%$ erythrocytes. The concentration of plant extracts was prepared at $(100 \mathrm{mg} / \mathrm{mL})$ and mixed with erythrocytes keeping the final volume up to $1 \mathrm{~mL}$. The cells were incubated at $37^{\circ} \mathrm{C}$ for $1 \mathrm{~h}$, then centrifuged at $1500 \mathrm{rpm}$ for $10 \mathrm{~min}$ and the supernatant was used to measure the absorbance of the liberated hemoglobin at $540 \mathrm{~nm}$ using the spectrophotometer (Bio Rad Laboratories, Kidlington, UK). Two controls were prepared without plant extracts; positive control, the cells were suspended in $0.1 \%$ Triton X-100 (complete hemolytic), and negative control, cells were suspended in normal saline [21]. The mixture was centrifuged at $1500 \mathrm{rpm} / \mathrm{a}$ minute, and the free hemoglobin in the supernatant was measured at $540 \mathrm{~nm}$. The hemolysis percentage was calculated by the following formula [24]:

$$
\% \text { hemolysis }=\frac{\text { At }-\mathrm{An}}{\mathrm{Ac}-\mathrm{An}} \times 100 \%
$$

At: absorbance of test sample

An: absorbance of the negative control (normal saline)

Ac: absorbance of the positive control (Triton X-100)

\subsubsection{MTT (Cell Proliferation) Assay \\ Preparation of Cell Lines for MTT Assay and Culture Condition}

Vero cell line (ATCC CCL-81) and human fibroblast (CO135C) were grown in Dulbecco's Modified Eagle Medium (DMEM) (Sigma, Hamburg, Germany) with high glucose contents, supplemented with 10\% Fetal bovine serum (FBS) (Sigma, Hamburg, Germany), glutamine $(2 \mathrm{mM})$, penicillin (100 units $/ \mathrm{mL}$ ) (Euroclone, Figino, Pero, Italy) and streptomycin $(100 \mu \mathrm{g} / \mathrm{mL})$ (Euroclone, Figino, Pero, Italy) and were cultured at $37{ }^{\circ} \mathrm{C}$ in a humidified $5 \% \mathrm{CO}_{2}$ and incubated for a week. The cells were diluted to a density of $1.5 \times 10^{4}$ cells /well for Vero cell and $1 \times 10^{4}$ cells/well for human fibroblast. The cells were treated with Camellia sinensis, Aloysia citrodora, Hibiscus sabdariffa, Glycyrrhiza glabra, and Thymus vulgaris according to manufacturer's instructions CellTiter-Glo. Eight concentrations $(500,400,300,200,100,50,25$, and $12.5 \mu \mathrm{g} / \mathrm{mL})$ were prepared from each selected plant extract. Exponentially growing cells were seeded (in $100 \mu \mathrm{L}$ of growth medium) in 96 well microtiter plates (Sigma, Hamburg, Germany) and incubated for 24-h incubation to form a partial monolayer. After that, the media was removed, added $100 \mu \mathrm{L}$ of the DMEM medium containing the plant extract (initially dissolved in DMSO), and reincubated for $24 \mathrm{~h}$. Then $15 \mu \mathrm{L}$ of the MTT solution (Promega, Madison, WI, USA) was added to each well and incubated for 1 to $4 \mathrm{~h}$. Blue crystals were formed after $4 \mathrm{~h}$ of cell contact with the MTT solution. Solubilization/stop solution $(100 \mu \mathrm{L})$ was added and incubated for another $1 \mathrm{~h}$. The absorbance can be recorded in $1 \mathrm{~h}$ or up to several days later. Untreated cells were used as negative control; doxorubicin (Indiamart, Vadodara, India) was used as a positive control and prepared in the same manner. Each treatment was repeated in triplicate. The optical density (OD) was measured at $590 \mathrm{~nm}$ using a microplate reader (BioTek, Winooski, 
VT, Uruguay) [19]. The percentage of the cell viability was calculated according to the following equation:

$$
\% \text { of the cell viability }=\frac{1-\text { OD of treated cells }}{\text { OD of untreated cells }} \times 100 \%
$$

\subsection{In Vivo Assay}

\subsubsection{Animals and Conditions}

A total of 140, seven-to-eight-week-old healthy mice with a bodyweight of 25-30 g were used in this study and maintained in the animal house at JUST. The mice were distributed randomly in isolate metallic cages. Mice were acclimated for a week under controlled conditions at $22{ }^{\circ} \mathrm{C}$ with relative humidity between $30 \%$ and $70 \%$ and $12 \mathrm{~h}$ variation of light and dark cycle. Treatment and the maintenance of the animals were in accordance with the Jordan University of Science and Technology Animal Care and Use Committee (project identification code, JUST-ACUC, Project \# 123/2018) which follows the international animal care and use guidelines (ILAR, 1996).

\subsubsection{Acute Toxicity Test}

The fixed-dose procedure for acute toxicity was carried out according to protocol OECD [25] for the evaluation of safety and efficacy of tested plants. Forty mice weighing around $25 \pm 2 \mathrm{~g}$ were randomly separated into four groups with 10 mice in each group (Group I: Camellia sinensis; group II: Aloysia citrodora; group III: Hibiscus sabdariffa; and group IV: water negative control). The mice were administered with a plant dose of $300 \mathrm{mg} / \mathrm{kg}$ of body weight by gavage-feeding once daily for two weeks. The negative control group received water only and animals were observed daily for 14 days. The clinical signs were observed including changes in skin and fur; changes in the eyes and mucous membranes, abnormal changes in behavior and activity, convulsions, salivation, diarrhea, sleep, and death.

\subsubsection{Mouse Systemic Infection Assay (Challenge Test) Bacterial Strains and Culture Conditions}

The MRSA strain was selected from the other four tested strains after mortality assay was performed, which caused the highest morbidity and mortality at bacterial concentration of $5.0 \times 10^{6} \mathrm{CFU} / \mathrm{mL}$ [26]. Furthermore, the challenge strain was resistant to methicillin (Oxoid, UK), cefixime (Oxoid, UK), oxacillin (Oxoid, UK), gentamycin (Oxoid, UK), and penicillin (Oxoid, UK). The pure culture was kept at $-80^{\circ} \mathrm{C}$, refreshed on MHB (Oxoid, UK) and subcultured on MHA media before use.

\section{Inoculum Preparation}

A single colony was inoculated in a $10 \mathrm{~mL}$ TSB and incubated in a shaker incubator (220 rpm) at $37^{\circ} \mathrm{C}$ overnight then diluted to reach the OD 0.132 at $600 \mathrm{~nm}$. The bacterial suspension was pelleted by centrifugation at $3500 \times g$ at $4{ }^{\circ} \mathrm{C}$ for $10 \mathrm{~min}$. The cell pellet was washed in $1 \mathrm{Xpbs}$ (phosphate buffer saline), centrifuged again under the same conditions, and finally resuspended in $2 \mathrm{~mL}$ saline to acquire the concentration of $5 \times 10^{6} \mathrm{CFU} / \mathrm{mL}$.

\section{Challenge Procedure}

Mice were divided into 9 groups (negative not infected or treated; positive infected not treated, 4 groups infected and treated with selected plants or vancomycin, and 3 groups infected and treated with combination of selected plant extracts), each group was 10 mice except the positive control was 20 mice and each mouse was inoculated intraperitoneally (ip) with $0.2 \mathrm{~mL}$ of bacterial suspension. The negative control group was inoculated with $0.2 \mathrm{~mL}$ TSB. Then mice received plant extracts or vancomycin at the dose of $300 \mathrm{mg} / \mathrm{kg}$ body weight by gavage-feeding once daily and continued for 7 days after infection. Mice were monitored daily and observed with a survival status. Mice that remained alive were sacrificed at the end of the eighth day of the challenge experiment. Visceral organs (heart, 
lung, liver, kidney, and spleen) were examined for pathological lesions. Visceral organs with lesions were subjected to histopathological examination. The severity of the damage on lung and liver were scored as follows: lung: normal (0), mild lesion: edema and fibrin (1), moderate lesion: small blood patches and moderate suppurative bronchitis (2), and severe lesion: large blood patches with severe suppurative bronchitis (3). Liver: normal (0) and abnormal lesion: suppurative hepatitis (1) [26].

\subsection{Statistical Analysis}

In vitro, experimental data were expressed as the mean $\pm \mathrm{SD}$. The results of the histopathological scoring system were analyzed using Kruskal-Wallis test and MannWhitney test. Only $p$-values of $\leq 0.05$ were considered statistically significant.

\section{Results}

\subsection{In Vitro Antibacterial Effect of Plant Extracts}

\subsubsection{Disc-Diffusion Assay}

Results revealed that 10 methanol plant extracts displayed different potent activities against an array of Gram positive and Gram negative bacteria (Table 2), of which, Camellia sinensis, Aloysia citrodora, Hibiscus sabdariffa, Thymus vulgaris, Phlomis brachyodon, Anchusa azurea and Glycyrrhiza glabra showed the highest antibacterial activity against MRSA isolates with an inhibition zone of 19.9, 19.3, 14.7, 14.5, 14.5, 13.9, and $13.1 \mathrm{~mm}$, respectively. Aloysia citrodora, Camellia sinensis, Glycyrrhiza glabra, Hibiscus sabdariffa, Thymus vulgaris, Phlomis brachyodon, and Anchusa azurea showed antibacterial activity against MSSA isolates with an inhibition zone of 20,19.5, 15.4, 14.6, 14.3, 14.2, and $13.1 \mathrm{~mm}$, respectively. E. coli were affected by Phlomis brachyodon (16.4 mm), Pallenis spinosa $(13.9 \mathrm{~mm})$, Urtica pilulifera and Anchusa azurea $(12.4 \mathrm{~mm})$ and Hibiscus sabdariffa $(11.5 \mathrm{~mm})$ while P. aeruginosa was not affected by any of the extracts except Hibiscus sabdariffa zone of inhibition $(12 \mathrm{~mm})$. Results of the antimicrobial activity of the tested plant extracts showed that $P$. aeruginosa was the most resistant isolate, followed by E. coli. Camellia sinensis and Aloysia citrodora showed the best antibacterial effects against $S$. aureus.

Table 2. Antibacterial activities of plant extracts against the tested bacteria.

\begin{tabular}{|c|c|c|c|c|c|c|c|c|}
\hline \multicolumn{9}{|c|}{ Antibacterial Activity (Zone of Inhibition, $\mathrm{mm}$ ) } \\
\hline $\begin{array}{c}\text { Plants } \\
(10 \mathrm{mg} / \mathrm{disc})\end{array}$ & $\begin{array}{c}\text { MRSA } \\
\text { ATCC } 43300\end{array}$ & $\begin{array}{c}\text { MRSA } \\
\text { Isolates }\end{array}$ & $\begin{array}{c}\text { MSSA } \\
\text { ATCC } 25923\end{array}$ & $\begin{array}{c}\text { MSSA } \\
\text { Isolates }\end{array}$ & $\begin{array}{c}\text { P.A. } \\
\text { ATCC } 9027\end{array}$ & $\begin{array}{c}\text { P.A } \\
\text { Isolates }\end{array}$ & $\begin{array}{c}\text { E. coli } \\
\text { NTCC } 0157\end{array}$ & $\begin{array}{c}\text { E. coli } \\
\text { Isolates }\end{array}$ \\
\hline Camellia sinensis & 22 & 19.9 & 23 & 19.5 & 9 & 8.5 & 0 & 0 \\
\hline Aloysia citrodora & 21 & 19.3 & 18 & 20 & 9 & 9.3 & 10 & 8.9 \\
\hline Hibiscus sabdariffa & 15 & 14.7 & 15 & 14.6 & 12 & 12 & 11 & 11.5 \\
\hline Glycyrrhiza glabra & 13 & 13.1 & 15 & 15.4 & 0 & 0 & 0 & 0 \\
\hline Phlomis brachyodon & 13 & 14.5 & 14 & 14.2 & 10 & 9.6 & 16 & 15.4 \\
\hline Thymus vulgaris & 15 & 14.5 & 15 & 14.3 & 0 & 0 & 0 & 0 \\
\hline Urtica pilulifera & 8 & 8.7 & 8 & 8.2 & 9 & 9.7 & 13 & 12.4 \\
\hline Anchusa azurea & 13.4 & 13.9 & 14 & 13.1 & 0 & 0 & 12 & 12.4 \\
\hline Plantago lanceolata & 12 & 12.3 & 12 & 12.5 & 0 & 0 & 0 & 0 \\
\hline Pallenis spinosa & 0 & 0 & 0 & 0 & 8 & 8.4 & 13 & 13.9 \\
\hline Vancomycin (30) & $20(S)$ & $18(\mathrm{~S})$ & $21(S)$ & $20(S)$ & NT & NT & NT & NT \\
\hline Gentamycin (10) & $26(S)$ & $25(\mathrm{~S})$ & $28(S)$ & $24(S)$ & $20(S)$ & $18(S)$ & $25(S)$ & $22(S)$ \\
\hline
\end{tabular}

Values of zones of inhibition are the mean of 10 tested MRSA, MSSA and E. coli isolates and five P. aeruginosa isolates. NT: Not tested; P.A: P. aeruginosa; R: resistant; S: susceptible.

\subsubsection{Minimum Inhibitory Concentration Assay (MIC) and Minimum Bactericidal Concentration Assay (MBC)}

Five of the most effective plant extracts; Camellia sinensis; Aloysia citrodora; Hibiscus sabdariffa; Glycyrrhiza glabra, and Thymus vulgaris were tested by MIC and MBC against S. aureus, E. coli, and P. aeruginosa. Plant extracts that showed a zone of inhibition $\geq 14 \mathrm{~mm}$ in disc diffusion test were tested by microdilution assay. Gentamycin and vancomycin were used as positive controls. Ten isolates for each of MRSA, MSSA and E. coli and five isolates of P. aeruginosa were tested. Results are presented in Table 3. Among the three bacterial species, the Camellia sinensis extract showed the highest antibacterial activity 
against S. aureus (MRSA and MSSA) with a MIC value $(0.5 \mathrm{mg} / \mathrm{mL})$. Extracts of Camellia sinensis and Aloysia citrodora displayed wide spectra of antibacterial activity in comparison to other plants. E. coli and P. aeruginosa showed the highest resistance profile in comparison to $S$. aureus.

Table 3. MIC and MBC results of plant extracts against selected bacterial species.

\begin{tabular}{|c|c|c|c|c|c|c|c|c|}
\hline \multirow{3}{*}{ Plant Extracts } & \multicolumn{8}{|c|}{ Minimum Inhibitory Concentration (MIC) and Minimum Bactericidal Concentration (MBC) (mg/mL) } \\
\hline & \multicolumn{2}{|c|}{ MRSA } & \multicolumn{2}{|c|}{ MSSA } & \multicolumn{2}{|c|}{ P. aeruginosa } & \multicolumn{2}{|c|}{ E. coli } \\
\hline & MIC & MBC & MIC & MBC & MIC & MBC & MIC & MBC \\
\hline Aloysia citrodora & $1.3 \pm 0.7$ & $2.5 \pm 1.4$ & $1.5 \pm 1.0$ & $2.8 \pm 1.7$ & $5.3 \pm 1.9$ & $9.4 \pm 4.0$ & $7.5 \pm 3.5$ & $15.0 \pm 7.0$ \\
\hline Camellia sinensis & $0.5 \pm 0.2$ & $0.8 \pm 0.4$ & $0.5 \pm 0.5$ & $1.1 \pm 0.9$ & $3.1 \pm 1.7$ & $5.6 \pm 3.6$ & NT & NT \\
\hline Hibiscus sabdariffa & $4.0 \pm 2.0$ & $9.2 \pm 4.1$ & $5.2 \pm 1.5$ & $9.9 \pm 3.1$ & $3.1 \pm 0$ & $6.3 \pm 0$ & $9.4 \pm 3.1$ & $19.9 \pm 6.9$ \\
\hline Glycyrrhiza glabra & $0.9 \pm 0.5$ & $1.8 \pm 1.0$ & $0.7 \pm 0.2$ & $1.4 \pm 0.3$ & $\mathrm{NT}^{1}$ & NT & NT & NT \\
\hline Thymus vulgaris & $5.5 \pm 4.9$ & $10.9 \pm 5.2$ & $4.0 \pm 1.6$ & $8.1 \pm 6.25$ & NT & NT & NT & NT \\
\hline Vancomycin $\mu \mathrm{g} / \mathrm{mL}$ & $1.56 \pm 0.50$ & $2.2 \pm 0.63$ & $1.9 \pm 0.93$ & $2.6 \pm 1.11$ & NT & NT & NT & NT \\
\hline Gentamycin $\mu \mathrm{g} / \mathrm{mL}$ & NT & NT & NT & NT & $5.6 \pm 1.96$ & $6.4 \pm 1.96$ & $4.6 \pm 0.92$ & $4.2 \pm 0.86$ \\
\hline
\end{tabular}

Values are mean $\pm \mathrm{SD} ;{ }^{1} \mathrm{NT}$ : not tested because zone of inhibition was $<14 \mathrm{~mm}$ in disc diffusion.

\subsection{Cytotoxicity Assay}

\subsubsection{The Erythrocyte Hemolysis}

None of the selected plant extracts (Camellia sinensis, Aloysia citrodora, Hibiscus sabdariffa, Thymus vulgaris, and Glycyrrhiza glabra) possess any hemolytic activity against human erythrocytes at $100 \mathrm{mg} / \mathrm{mL}$ (Figure 1). The highest hemolytic activity was found by methanolic extract of the Hibiscus sabdariffa, and the minimum activity was by Glycyrrhiza glabra.

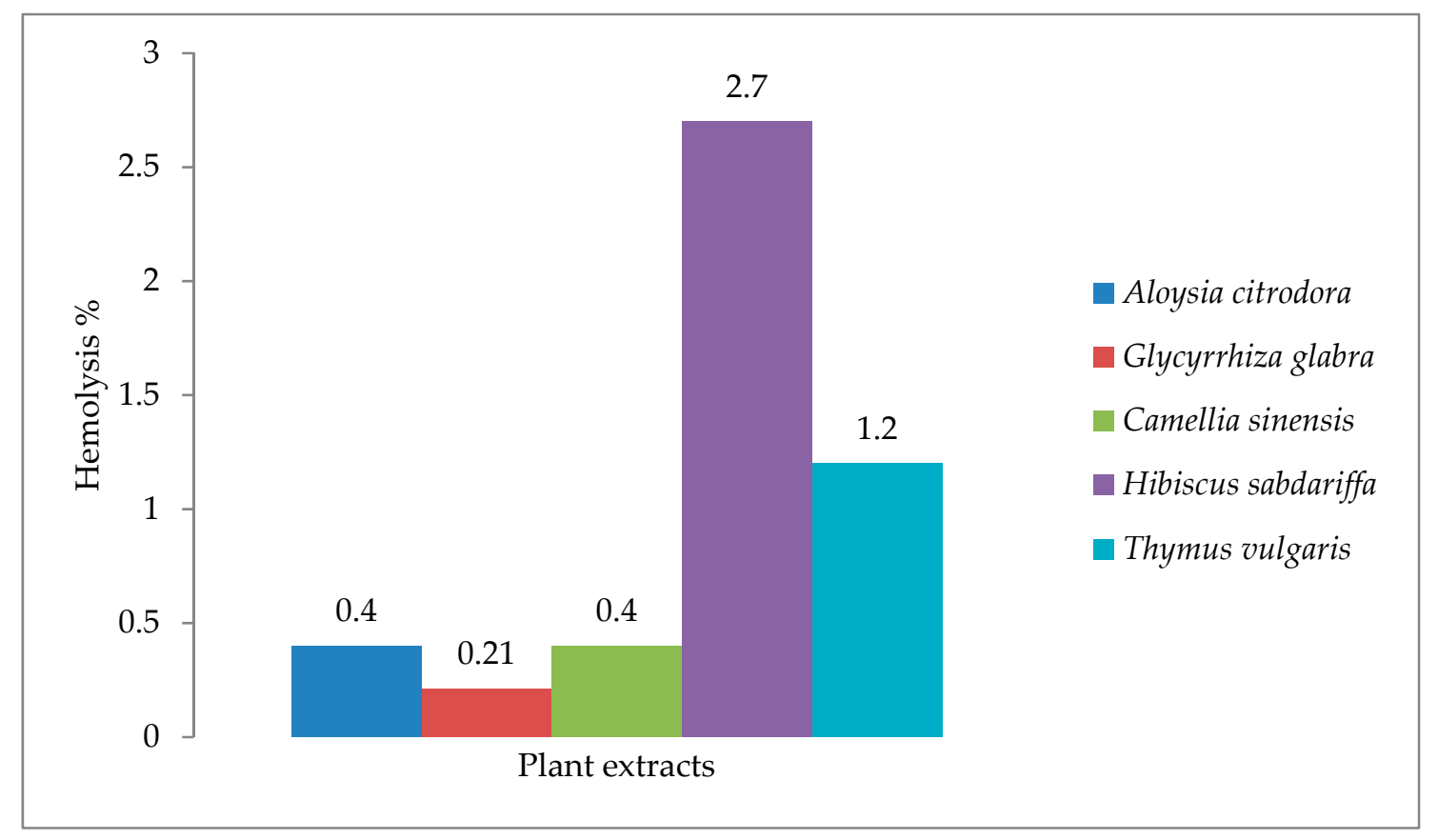

Figure 1. Toxicity effects of selected plant extracts against human erythrocytes.

\subsubsection{MTT Assay}

To explore the possible biological activity of the plant extracts, it was further evaluated by in vitro antiproliferative characteristics on two normal cell lines; human fibroblast cell lines and monkey Vero cell lines. This study showed no toxicity at the tested concentrations on both Vero and fibroblast cell lines (Figure 2A,B). 


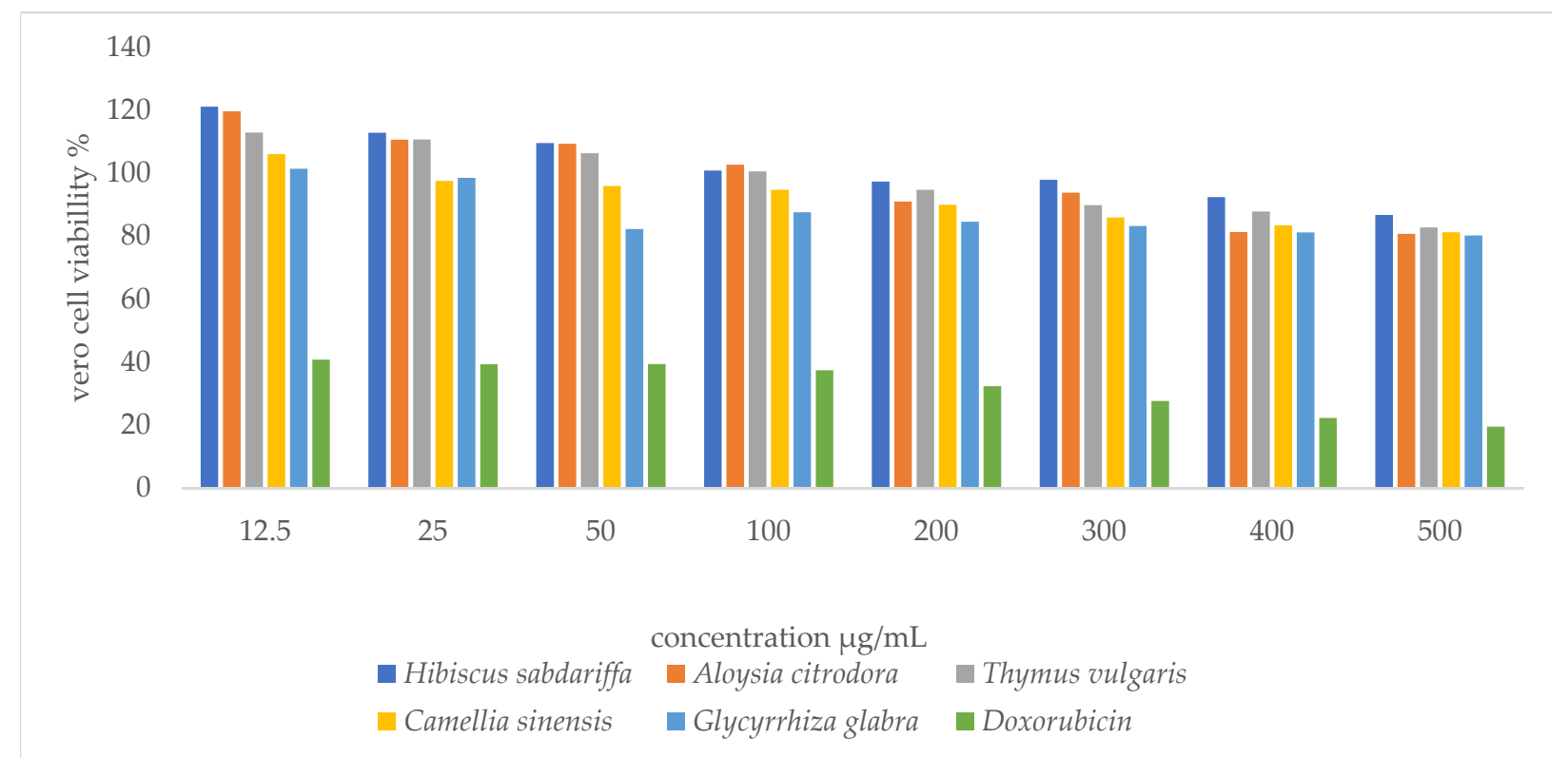

(A)

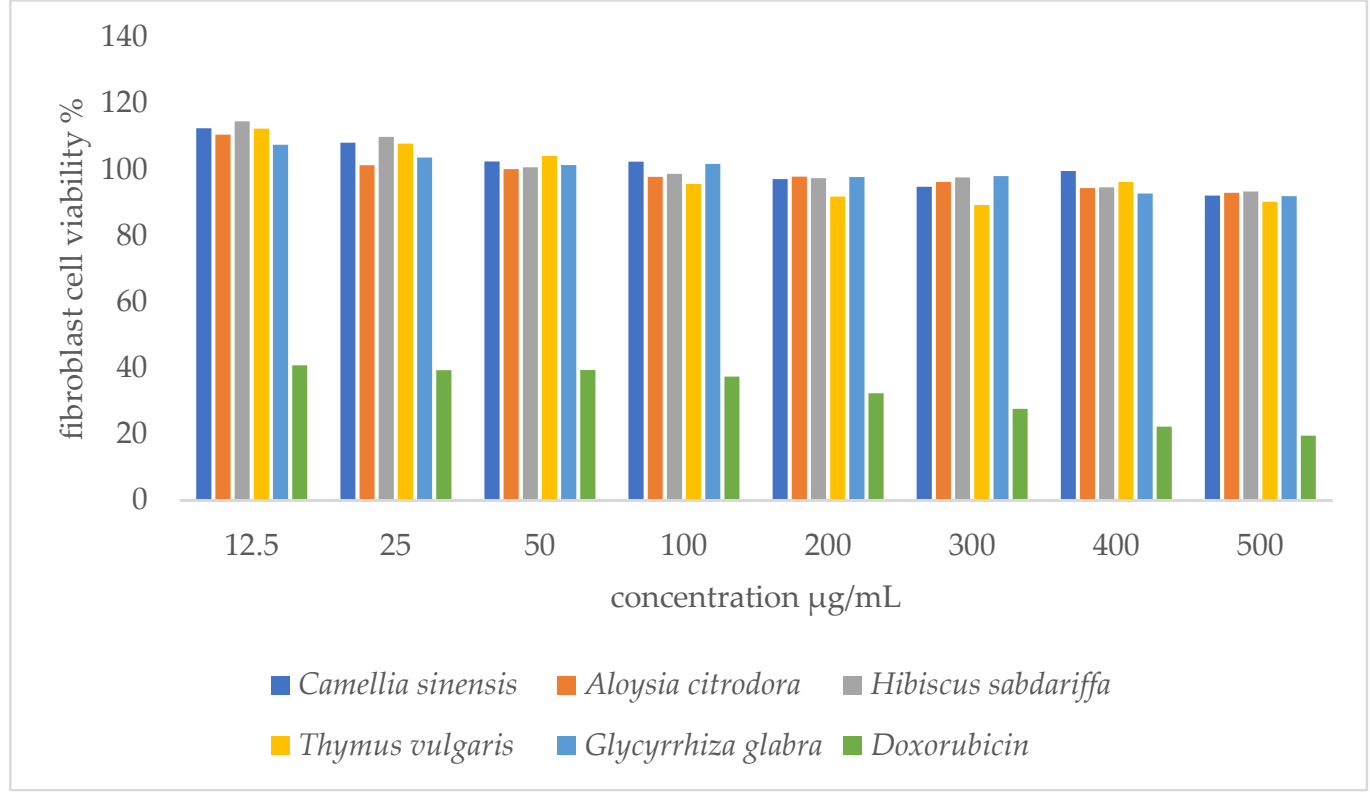

(B)

Figure 2. (A) Toxicity of selected plant extracts against Vero cell lines; (B) Toxicity of selected plant extracts against human fibroblast cell lines.

\subsection{In Vivo Assay}

\subsubsection{Acute Cytotoxicity}

Mice were given $300 \mathrm{mg} / \mathrm{kg}$ body weight dose of the plant extracts (Camellia sinensis, Aloysia citrodora, and Hibiscus sabdariffa). Administered plant extracts did not cause any toxicity symptoms, adverse effects, or mortality up to two-week post-induction in any of the plant-treated groups. All mice in the acute toxicity study showed similar visual characteristics to that of the negative control group. There were no changes in the skin, fur, eyes, mucous membranes, respiration, locomotion, convulsion, salivation, or sleep in any of the mice during the days of the study. After two weeks of the acute toxicity experiment, there were no significant differences observed in gross lesions among different groups. The vital organs (heart, lung, liver, kidneys, and spleen) from treated mice revealed no significant difference when compared with the untreated negative control group. 


\subsubsection{Systemic Infection and Treatment Experiment (Challenge Test)}

In the negative control group, no significant gross pathological changes were seen in the examined mice. All organs were normal. While in the positive control group, there were remarkable gross changes within different organs. These changes were exhibited as kidney congestion with multifocal to coalescing abscesses, diffuse blood patches in lungs with severe bronchopneumonia, and congested hearts and livers. Upon histopathological study, the positive control was affected by chronic suppurative bronchitis; accompanied by severing lymphocytic perivascular infiltrate with multifocal suppurative hepatitis.

The effect of plant extracts in infected mice and mortality rate are presented in Table 4. Two of the ten mice treated with Camellia sinensis had mild suppurative bronchopneumonia. Two infected mice in Aloysia citrodora treated group had visible multifocal blood patches in the lung, and histopathological changes ranged from moderate to severe suppurative bronchitis with mild hepatitis. Mice in Hibiscus sabdariffa treatment group showed moderate to severe suppurative bronchitis and moderate hepatitis, the entire liver also exhibited accentuated lobular pattern. The combination of the tested plant extracts demonstrated that the Camellia sinensis had a synergistic effect and caused a reduction of infection when used with Hibiscus sabdariffa or Aloysia citrodora.

Table 4. Effects of plant extract treatment on clinical outcome of MRSA infected mice at 8 days post-infection following treatment with tested plants and vancomycin; mortality, gross lesions of lung and liver, and percentage of histopathological score for lung and liver.

\begin{tabular}{|c|c|c|c|c|c|c|c|c|c|}
\hline \multirow[b]{2}{*}{ Groups } & \multirow[b]{2}{*}{ Mortality \% } & \multicolumn{2}{|c|}{ Gross Lesion of 10 Mice } & \multicolumn{4}{|c|}{ Lungs Lesion Scores \% } & \multicolumn{2}{|c|}{ Liver Lesion Scores \% } \\
\hline & & $\begin{array}{c}\text { Total No. of } \\
\text { Abnormal Lungs }\end{array}$ & $\begin{array}{c}\text { Total No. of } \\
\text { Abnormal Liver }\end{array}$ & Normal & Mild & Moderate & Severe & Normal & Abnormal \\
\hline G1: Negative Control & 0 & 00 & 00 & 100 & 0 & 0 & 0 & 100 & 0 \\
\hline G2: Positive Control & 15 & 20 & 20 & 0 & 0 & 0 & 100 & 15 & 85 \\
\hline G3: Camellia sinensis & 0 & 2 & 00 & 80 & 10 & 10 & 0 * & 100 & 0 * \\
\hline G4: Aloysia citrodora & 0 & 5 & 1 & 50 & 30 & 20 & 0 * & 90 & $10 *$ \\
\hline G5: Hibiscus sabdariffa & 0 & 6 & 3 & 40 & 40 & 20 & $0 *$ & 70 & $30 *$ \\
\hline $\begin{array}{l}\text { G6: Camellia sinensis } \\
\text { and Aloysia citrodora }\end{array}$ & 0 & 4 & 0 & 60 & 30 & 10 & $0 *$ & 100 & $0 *$ \\
\hline $\begin{array}{l}\text { G7: Camellia sinensis } \\
\text { and Hibiscus sabdariffa }\end{array}$ & 0 & 6 & 2 & 40 & 40 & 20 & $0 *$ & 80 & $20 *$ \\
\hline $\begin{array}{l}\text { G8: Hibiscus sabdariffa } \\
\text { and Aloysia citrodora }\end{array}$ & 0 & 6 & 2 & 40 & 30 & 30 & $0 *$ & 80 & $20 *$ \\
\hline $\begin{array}{l}\text { G9: Vancomycin } \\
\text { control }\end{array}$ & 0 & 7 & 2 & 30 & 30 & 40 & 0 * & 80 & $20 *$ \\
\hline
\end{tabular}

Number of mice in each group was 10 mice except the positive control was 20 mice, ${ }^{*}$ Significant: $p \leq 0.05$.

All treated plant groups showed a significant reduction of lesions compared with the infected untreated group $(p<0.05)$. Camellia sinensis treated group was highly similar to that of the negative control. Moreover, the liver lesion was a common feature of mice subjected to Hibiscus sabdariffa.

\section{Discussion}

Antibiotic resistance is one of the major threats to global health and bacterial resistance is steadily increasing [27]. Misuse of antibiotics has accelerated the antibiotic resistance process which has become harder to treat [6]. The present study has focused on using plants to combat bacterial infections. Plants are considered the richest bioactive secondary metabolites which have become essential to screen potential as sources of antimicrobial agents against a wide range of MDR bacteria $[10,19,28]$. An increasing interest in studying herbal remedies worldwide was observed because it is safe and effective [23,26,29].

In the present investigation, in vitro antibacterial activities of 60 plant extracts were evaluated for their antibacterial activity against MRSA, MSSA. ESBL E. coli and MDR P. aeruginosa isolated from human and animals. Ten of them (Camellia sinensis, Aloysia citrodora, Hibiscus sabdariffa, Glycyrrhiza glabra, Phlomis brachyodon, Thymus vulgaris, Urtica pilulifera, Anchusa azurea, Plantago, and Pallenis spinosa) exhibited the highest antibacterial activity. The highest inhibitory zone was for extracts of Camellia sinensis, Aloysia citrodora, Hibiscus sabdariffa, Thymus vulgaris, Glycyrrhiza glabra, Anchusa azurea, and Phlomis brachy- 
odon against MRSA and MSSA; this is similar to [30], Gram positive bacteria were more sensitive than Gram negative bacteria. ESBL E. coli were affected by Phlomis brachyodon, Pallenis spinosa, Urtica pilulifera, Anchusa azurea, Aloysia citrodora, and Hibiscus sabdariffa. Camellia sinensis showed the greatest antimicrobial effect when compared to the other plants, this is in agreement with the results of [22]. In contrast, $P$. aeruginosa was not affected by any of the extracts except Hibiscus sabdariffa and not in agreement with the results of [22] results that Hibiscus sabdariffa extract had no antimicrobial activity against Gram positive and Gram negative bacteria.

All plants display (MIC) values less than $8 \mathrm{mg} / \mathrm{mL}$ in MIC test are considered as antimicrobial agents [31]. Camellia sinensis and Aloysia citrodora exhibited wide spectra of antimicrobial activity in comparison to Hibiscus sabdariffa, Glycyrrhiza glabra, and Thymus vulgaris (Table 3). Among the three tested bacterial species, Camellia sinensis extract showed the highest antibacterial activity against $S$. aureus (MRSA and MSSA), exhibiting the lowest MIC value $(0.5 \mathrm{mg} / \mathrm{mL})$ which is in agreement with the report of [22]. Additionally, Camellia sinensis has anti-bacterial activity against MDR P. aeruginosa, which is similar to a previous report [32]. Aloysia citrodora showed a MIC value of $1.3 \mathrm{mg} / \mathrm{mL}$ and $5.3 \mathrm{mg} / \mathrm{mL}$ against MRSA and P. aeruginosa, respectively, which is in agreement with [33], were essential oils of Aloysia citrodora possessed significant antibacterial effect against both Gram negative and Gram positive bacteria, with MICs ranged between 2.84 and $8.37 \mathrm{mg} / \mathrm{mL}$. Furthermore, there were no differences between the effects of plant extracts against MRSA and MSSA that is similar to the report of [34]. The infection severity of MRSA is due to lack of therapeutic options, but not due to it is virulence [34]. Gram negative bacteria (E. coli and $P$. aeruginosa) were less susceptible to antibacterial plant extracts which may be due to their outer membrane lipopolysaccharides, which is similar to the report of [35]. The antibacterial effects were higher against $S$. aureus and comparatively lower in the case of Salmonella and E. coli [35]. Results of this study are also consistent with many previous reports, which find a good indication for the potential of some plants to be applied as antimicrobial to treat bacterial infections $[13,19]$.

The toxicity of plant extract needs scientific validation to ensure it is safe to use by humans $[19,33]$. Our results indicated that Camellia sinensis, Aloysia citrodora, Hibiscus sabdariffa, Thymus vulgaris, Glycyrrhiza glabra did not have any toxicity at $100 \mathrm{mg} / \mathrm{mL}$ using erythrocyte hemolysis assay. This is similar to the report of [24,36]. It is also worth mentioning that our results of the cytotoxicity assay are in agreement with many previous studies that investigated plants toxicity on human fibroblast and monkey Vero cell lines $[24,29,33]$. The results of the in vitro MTT assay showed no cytotoxicity for all tested plants when compared with doxorubicin, which is used as a positive control [37].

Our challenge study demonstrated that MRSA-induced systemic infection after estimated acute cytotoxicity. All mice in the acute toxicity study were within normal limits. According to our results, Camellia sinensis, Aloysia citrodora, and Hibiscus sabdariffa are safe to use as remedy which is in agreement with the results of $[38,39]$. The previous three plants showed a significant decrease in the severity of the in vivo MRSA infection compared to the positive control. Camellia sinensis treated group has the most protective ability against MRSA infections among all groups including vancomycin, which is consistent with [35] results of the Camellia sinensis seed saponins which possess strong antibacterial activities against infected chickens by E. coli, S. aureus, and Salmonella [35]. In recent years reduced vancomycin susceptibility of MRSA was noted [40] which is consistent with our results. The activity of Aloysia citrodora extract was improved when combined with Camellia sinensis. Hence, the combination effects indicated synergistic efficacy. However, combinations of Camellia sinensis with Hibiscus sabdariffa were antagonists. In general, the synergistic effects of the combination of different herbs with various bioactive constituents have shown progressive protective effects [41,42]. 


\section{Conclusions}

This study gives important data regarding in vivo antimicrobial efficacy of plant extract. in vitro results of this study are consistent with the in vivo results. Camellia sinensis, Aloysia citrodora, and Hibiscus sabdariffa have significant potent antimicrobial activity against MDR bacteria with no toxicity toward eukaryotic cells. Camellia sinensis has also significant potent antimicrobial activity against MRSA. Ongoing phytochemical research is required to investigate new bioactive compounds derived from plants that possess antimicrobial effects and focusing on the synergistic effect of different plant extracts and antibiotics to enhance the effectiveness of antimicrobial drugs against MDR bacteria. Alongside this, further studies are needed to determine the adverse effects, detect LD 50, toxicity for the acute and chronic effect of plant extracts, and study the mode of action of plant extracts in vivo before they can be used as therapeutic agents.

Author Contributions: The idea of this study was of Y.H.T. and S.M.B.B. The laboratory work was executed by W.A.A. under the supervision of Y.H.T. and S.M.B.B. at the Research Microbiology Laboratory, Department of Basic Veterinary Medical Sciences, Faculty of Veterinary Medicine, Jordan University of Science and Technology, Irbid-Jordan. Authors participated in writing, revising, and approving the article. All authors have read and agreed to the published version of the manuscript.

Funding: This research was funded by the Deanship of research/Jordan University of Science and Technology.

Institutional Review Board Statement: Treatment and maintenance of the animals were in accordance with the Jordan University of Science and Technology Animal Care and Use Committee (project identification code, JUST-ACUC, Project \# 123/2018) which follows the international animal care and use guidelines (ILAR, 1996).

Informed Consent Statement: Not applicable.

Acknowledgments: Authors acknowledge the Deanship of research/JUST for their financial support and would like to thank Tamam M. El-Elimat, Faculty of Pharmacy (JUST) for providing the plant extracts and for Manal M. Abbas, Al-Ahliyya Amman University, who helped in preparing.

Conflicts of Interest: The authors declare no conflict of interest.

\section{References}

1. Martinez, J.L. General principles of antibiotic resistance in bacteria. Drug Discov. Today Technol. 2014, 11, 33-39. [CrossRef]

2. Cilloniz, C.; Martin-Loeches, I.; Garcia-Vidal, C.; San Jose, A.; Torres, A. Microbial Etiology of Pneumonia: Epidemiology, Diagnosis and Resistance Patterns. Int. J. Mol. Sci. 2016, 17, 2120. [CrossRef]

3. Spellberg, B.; Gilbert, D.N. The future of antibiotics and resistance: A tribute to a career of leadership by John Bartlett. Clin. Infect. Dis. 2014, 59 (Suppl. 2), S71-S75. [CrossRef]

4. Aslam, B.; Wang, W.; Arshad, M.I.; Khurshid, M.; Muzammil, S.; Rasool, M.H.; Nisar, M.A.; Alvi, R.F.; Aslam, M.A.; Qamar, M.U.; et al. Antibiotic resistance: A rundown of a global crisis. Infect. Drug Resist. 2018, 11, 1645-1658. [CrossRef] [PubMed]

5. Spellberg, B.; Blaser, M.; Guidos, R.J.; Boucher, H.W.; Bradley, J.S.; Eisenstein, B.I.; Gerding, D.; Lynfield, R.; Reller, L.B.; Rex, J.; et al. Combating antimicrobial resistance: Policy recommendations to save lives. Clin. Infect. Dis. 2011, 52 (Suppl. 5), S397-S428. [PubMed]

6. CDC. Antibiotic Resistance Threats in the United States. Available online: https:/ /www.cdc.gov/drugresistance/threat-report2013/pdf/ar-threats-2013-508.pdf (accessed on 1 July 2021).

7. Katiyar, C.; Gupta, A.; Kanjilal, S.; Katiyar, S. Drug discovery from plant sources: An integrated approach. AYU 2012, 33, $10-19$. [CrossRef]

8. Abreu, A.C.; McBain, A.J.; Simões, M. Plants as sources of new antimicrobials and resistance-modifying agents. Nat. Prod. Rep. 2012, 29, 1007-1021. [CrossRef]

9. Silva, L.N.; Zimmer, K.R.; Macedo, A.J.; Trentin, D.S. Plant Natural Products Targeting Bacterial Virulence Factors. Chem. Rev. 2016, 116, 9162-9236. [CrossRef] [PubMed]

10. Cowan, M.M. Plant products as antimicrobial agents. Clin. Microbiol. Rev. 1999, 12, 564-582. [CrossRef] [PubMed]

11. Gupta, P.D.; Birdi, T.J. Development of botanicals to combat antibiotic resistance. J. Ayurveda Integr. Med. 2017, 8, $266-275$. [CrossRef] [PubMed]

12. Subramani, R.; Narayanasamy, M.; Feussner, K.D. Plant-derived antimicrobials to fight against multi-drug-resistant human pathogens. 3 Biotech 2017, 7, 172. [CrossRef] [PubMed] 
13. Ali-Shtayeh, M.S.; Yaghmour, R.M.; Faidi, Y.R.; Salem, K.; Al-Nuri, M.A. Antimicrobial activity of 20 plants used in folkloric medicine in the Palestinian area. J. Ethnopharmacol. 1998, 60, 265-271. [CrossRef]

14. Truong, D.-H.; Nguyen, D.H.; Ta, N.T.A.; Bui, A.V.; Do, T.H.; Nguyen, H.C. Evaluation of the Use of Different Solvents for Phytochemical Constituents, Antioxidants, and in vitro Anti-Inflammatory Activities of Severinia buxifolia. J. Food Qual. 2019, 2019, 1-9. [CrossRef]

15. Al-Qura'n, S. Ethnopharmacological survey of wild medicinal plants in Showbak, Jordan. J. Ethnopharmacol. 2009, 123, 45-50. [CrossRef] [PubMed]

16. WHO Traditional Medicine Strategy 2014-2023. Available online: https://www.who.int/publications/i/item/9789241506096 (accessed on 1 July 2021).

17. Vickers, A.; Zollman, C. ABC of complementary medicine: Herbal medicine. BMJ 1999, 319, 1050-1053. [CrossRef]

18. Fendrihan, S.; Pop, C.E. Biotechnological potential of plant associated microorganisms. Rom. Biotechnol. Lett. 2021, 26, $2700-2706$. [CrossRef]

19. Talib, W.H.; Mahasneh, A.M. Antimicrobial, cytotoxicity and phytochemical screening of Jordanian plants used in traditional medicine. Molecules 2010, 15, 1811-1824. [CrossRef] [PubMed]

20. Jo, H.Y.; Kim, Y.; Park, H.W.; Moon, H.E.; Bae, S.; Kim, J.; Kim, D.G.; Paek, S.H. The Unreliability of MTT Assay in the Cytotoxic Test of Primary Cultured Glioblastoma Cells. Exp. Neurobiol. 2015, 24, 235-245. [CrossRef] [PubMed]

21. Zohra, A.F.M. Hemolytic activity of different herbal extracts used in Algeria. Int. J. Pharma Sci. Res. 2014, 5, 495-500.

22. Ibrahim, D.A.; Albadani, R.N. Evaluation of the Potential Nephroprotective and Antimicrobial Effect of Camellia sinensis Leaves versus Hibiscus sabdariffa (in vivo and in vitro Studies). Adv. Pharmacol. Sci. 2014, 2014, 389834.

23. Al-Mamun, M.A.; Akter, Z.; Uddin, M.J.; Ferdaus, K.M.; Hoque, K.M.; Ferdousi, Z.; Reza, M.A. Characterization and evaluation of antibacterial and antiproliferative activities of crude protein extracts isolated from the seed of Ricinus communis in Bangladesh. BMC Complement. Altern. Med. 2016, 16, 211. [CrossRef]

24. Mehreen, A.; Waheed, M.; Liaqat, I.; Arshad, N. Phytochemical, Antimicrobial, and Toxicological Evaluation of Traditional Herbs Used to Treat Sore Throat. Biomed. Res. Int. 2016, 2016, 8503426. [CrossRef] [PubMed]

25. OECD. Oecd Guideline for Testing of Chemicals; OECD: Paris, France, 2001; Volume 12, pp. 1-14.

26. Arshad, N.; Mehreen, A.; Liaqat, I.; Arshad, M.; Afrasiab, H. In vivo screening and evaluation of four herbs against MRSA infections. BMC Complement. Altern. Med. 2017, 17, 498. [CrossRef]

27. van Elsas, J.D.; Bailey, M.J. The ecology of transfer of mobile genetic elements. FEMS Microbiol. Ecol. 2002, 42, 187-197. [CrossRef]

28. Tarawneh, K.A.; Irshaid, F.; Jaran, A.S.; Ezealarab, M.; Khleifat, K.M. Evaluation of Antibacterial and Antioxidant Activities of Methanolic Extracts of Some Medicinal Plants in Northern Part of Jordan. J. Biol. Sci. 2010, 10, 325-332. [CrossRef]

29. Talib, W.H.; Zarga, M.H.; Mahasneh, A.M. Antiproliferative, antimicrobial and apoptosis inducing effects of compounds isolated from Inula viscosa. Molecules 2012, 17, 3291-3303. [CrossRef] [PubMed]

30. Koohsari, H.; Ghaemi, E.A.; Sheshpoli, M.S.; Jahedi, M.; Zahiri, M. The investigation of antibacterial activity of selected native plants from North of Iran. J. Med. Life 2015, 8, 38-42.

31. Fabry, W.; Okemo, P.O.; Ansorg, R. Antibacterial activity of East African medicinal plants. J. Ethnopharmacol. 1998, 60, 79-84. [CrossRef]

32. Radji, M.; Agustama, R.A.; Elya, B.; Tjampakasari, C.R. Antimicrobial activity of green tea extract against isolates of methicillinresistant Staphylococcus aureus and multi-drug resistant Pseudomonas aeruginosa. Asian Pac. J. Trop. Biomed. 2013, 3, 663-667. [CrossRef]

33. Oukerrou, M.A.; Tilaoui, M.; Mouse, H.A.; Leouifoudi, I.; Jaafari, A.; Zyad, A. Chemical Composition and Cytotoxic and Antibacterial Activities of the Essential Oil of Aloysia citriodora Palau Grown in Morocco. Adv. Pharmacol. Sci. 2017, 2017, 7801924. [CrossRef]

34. Teow, S.Y.; Liew, K.; Ali, S.A.; Khoo, A.S.; Peh, S.C. Antibacterial Action of Curcumin against Staphylococcus aureus: A Brief Review. J. Trop. Med. 2016, 2016, 2853045. [CrossRef]

35. Khan, M.I.; Ahhmed, A.; Shin, J.H.; Baek, J.S.; Kim, M.Y.; Kim, J.D. Green Tea Seed Isolated Saponins Exerts Antibacterial Effects against Various Strains of Gram Positive and Gram Negative Bacteria, a Comprehensive Study in vitro and in vivo. Evid. Based Complement. Altern. Med. 2018, 2018, 3486106. [CrossRef] [PubMed]

36. Ramchoun, M.; Sellam, K.; Harnafi, H.; Alem, C.; Benlyas, M.; Khallouki, F.; Amrani, S. Investigation of antioxidant and antihemolytic properties of Thymus satureioides collected from Tafilalet Region, south-east of Morocco. Asian Pac. J. Trop. Biomed. 2015, 5, 93-100. [CrossRef]

37. Sabeti, B.; Noordin, M.I.; Mohd, S.; Hashim, R.; Dahlan, A.; Javar, H.A. Development and characterization of liposomal doxorubicin hydrochloride with palm oil. Biomed. Res. Int. 2014, 2014, 765426. [CrossRef] [PubMed]

38. Chan, P.C.; Ramot, Y.; Malarkey, D.E.; Blackshear, P.; Kissling, G.E.; Travlos, G.; Nyska, A. Fourteen-week toxicity study of green tea extract in rats and mice. Toxicol. Pathol. 2010, 38, 1070-1084. [CrossRef]

39. Meena, A.K.; Jain, A.; Pendey, K.; Singh, R.K. Acute Toxicity and Genotoxic Activity of Hibiscus rosa sinensis Flower Extract. Am. J. Phytomed. Clin. Ther. 2014, 2, 524-529.

40. Howden, B.P.; Davies, J.K.; Johnson, P.D.; Stinear, T.P.; Grayson, M.L. Reduced vancomycin susceptibility in Staphylococcus aureus, including vancomycin-intermediate and heterogeneous vancomycin-intermediate strains: Resistance mechanisms, laboratory detection, and clinical implications. Clin. Microbiol. Rev. 2010, 23, 99-139. [CrossRef] [PubMed] 
41. Kuok, C.F.; Hoi, S.O.; Hoi, C.F.; Chan, C.H.; Fong, I.H.; Ngok, C.K.; Meng, L.R.; Fong, P. Synergistic antibacterial effects of herbal extracts and antibiotics on methicillin-resistant Staphylococcus aureus: A computational and experimental study. Exp. Biol. Med. (Maywood) 2017, 242, 731-743. [CrossRef]

42. Nayim, P.; Mbaveng, A.T.; Wamba, B.E.N.; Fankam, A.G.; Dzotam, J.K.; Kuete, V. Antibacterial and Antibiotic-Potentiating Activities of Thirteen Cameroonian Edible Plants against Gram-Negative Resistant Phenotypes. Sci. World J. 2018, $2018,4020294$. [CrossRef] 